\title{
Optimization of Amide-Based Inhibitors of Soluble Epoxide Hydrolase with Improved Water Solubility
}

\author{
In-Hae Kim, Fenton R. Heirtzler, Christophe Morisseau, Kosuke Nishi, Hsing-Ju Tsai, and \\ Bruce D. Hammock \\ Department of Entomology and University of California Davis Cancer Center, University of \\ California, One Shields Avenue, Davis, California 95616
}

\section{Abstract}

Soluble epoxide hydrolase (sEH) plays an important role in the metabolism of endogenous chemical mediators involved in the regulation of blood pressure and inflammation. 1,3-Disubstituted ureas with a polar group located on the fifth atom from the carbonyl group of urea function are active inhibitors of sEH both in vitro and in vivo. However, their limited solubility in water and relatively high melting point lead to difficulties in formulating the compounds and poor in vivo efficacy. To improve these physical properties, the effect of structural modification of the urea pharmacophore on the inhibition potencies, water solubilities, octanol/water partition coefficients $(\log P)$, and melting points of a series of compounds was evaluated. For murine sEH, no loss of inhibition potency was observed when the urea pharmacophore was modified to an amide function, while for human sEH 2.5 -fold decreased inhibition was obtained in the amide compounds. In addition, a NH group on the right side of carbonyl group of the amide pharmacophore substituted with an adamantyl group (such as compound 14) and a methylene carbon present between the adamantyl and amide groups were essential to produce potent inhibition of sEH. The resulting amide inhibitors have 10-30-fold better solubility and lower melting point than the corresponding urea compounds. These findings will facilitate synthesis of sEH inhibitors that are easier to formulate and more bioavailable.

\section{Introduction}

In humans, soluble epoxide hydrolase (sEH; EC 3.3.2.3) is involved in the metabolism of endogenous chemical mediators such as arachidonic acid, ${ }^{1}$ linoleic acid, ${ }^{2}$ and other lipid epoxides. ${ }^{3}$ Epoxides of arachidonic acid (epoxyeicosatrienoic acids or EETs) are known as effective modulators of blood pressure. ${ }^{4}$ However, hydrolyzed metabolites of EETs, dihydroxyeicosatrienoic acids (DHETs), generated by sEH diminish this activity. ${ }^{4}$ We have reported that treatment with effective $\mathrm{sEH}$ inhibitors significantly reduces the blood pressure of spontaneous hypertensive rats and angiotensin II induced hypertension in rats. ${ }^{5-7}$

Furthermore, male knockout sEH mice have significantly lower blood pressure than wild-type mice, ${ }^{8}$ supporting the role of sEH in blood pressure regulation. In addition, the EETs have demonstrated further vascular protective effects such as antiinflammatory properties in endothelial cells, ${ }^{9-12}$ suppression of reactive oxygen species following hypoxiareoxygenation, ${ }^{13}$ attenuation of vascular smooth muscle migration, ${ }^{14}$ and enhancement of a fibrinolytic pathway. ${ }^{15}$ In both cellular and animal models, continued efficacy of EETmediated hypertension and cardioprotective effects including inflammation control is dependent upon epoxide hydrolysis by $\mathrm{sEH},{ }^{2}, 16$ suggesting that the inhibitors of the $\mathrm{sEH}$ will

\footnotetext{
*To whom correspondence should be addressed at the Department of Entomology. Phone: 530-752-7519. Fax: 530-752-1537. E-mail: bdhammock@ucdavis.edu.

Supporting Information Available: Syntheses and detailed analytical data for compounds 3, a-2, a-3, b-2, b-3, c-2, c-3, d-2, d-3,

10-12, 16, and 17. This material is available free of charge via the Internet at http://pubs.acs.org.
} 
be effective therapeutic agents for hypertension, inflammation, and other disorders that can be addressed by changing the in vivo concentration of EET.

We previously reported 1,3-disubsituted ureas (and related carbamates and amides) as very potent and stable inhibitors of sEH. These compounds are competitive, tight-binding inhibitors with nanomolar $K_{\mathrm{I}}$ values that interact stoichiometrically with purified recombinant sEH. ${ }^{16}$ These inhibitors efficiently reduce epoxide hydrolysis in several in vitro and in vivo models. $6,16,17$ However, these dialkyl inhibitors have limited solubility in water and high melting point, which likely affect their in vivo efficacy and make formulation difficult. 5,18 Recently, we reported that compounds with a polar functional group located on the fifth/sixth atom from the carbonyl group of the urea pharmacophore are potent inhibitors, and their solubility in water is also improved without drop of the inhibition potency. ${ }^{19}$ Analysis of the X-ray crystal structure of the murine sEH with 1-cyclohexyl-3-dodecylurea (CDU), a sEH dialkylurea inhibitor, that the urea is bound by hydrogen bonding between the phenol groups of $\mathrm{Tyr}^{381}$ and $\mathrm{Tyr}^{465}$, and the carbonyl of the urea, while a salt bridge is formed between one of the urea $\mathrm{N}-$ $\mathrm{H}$ and $\mathrm{Asp}^{333}$ (Figure 1). ${ }^{20,21}$ As illustrated in Figure 1, Gln ${ }^{382}$ and $\operatorname{Trp}^{334}$, both conserved residues, form a possible hydrogen-bonding site for a polar group present at around the fifth or sixth atom (approximately $7.5 \AA$ ) from the urea carbonyl group. The presence of a functionalized group at this position helps improve the binding of the inhibitor to the enzyme due to additional hydrogen binding. However, the positive effect on the solubility in water of the inhibitor is still quite limited $(<2 \mu \mathrm{g} / \mathrm{mL})$ and the resulting compounds still have relatively high melting points $\left(>100^{\circ} \mathrm{C}\right) .{ }^{19}$ Therefore, in the present study, we report the effect of changes in the structure of inhibitors functionalized with a polar group on the inhibition potency and physical properties (e.g. water solubility, $\log P$, and melting point), specifically modifying the urea central pharmacophore to design potent $\mathrm{SEH}$ inhibitors with improved solubility in water.

\section{Chemistry}

\section{Syntheses}

Compounds in Tables 1 and 2, and compounds 5 and $\mathbf{6}$ in Table 3 were prepared according to the procedures reported previously. ${ }^{19}$ The syntheses of 3 -chlorophenyl or 1-

adamantylcarbarmoylpentanoic acid pentyl esters ( $\mathbf{7}$ and $\mathbf{1 3}$ ) are described in part A of Scheme 1, and 3-chlorophenylacetyl-, 1-adamantylacetyl-, or 1-adamantylcarbonylaminobutyric acid pentyl ester $(\mathbf{8}, \mathbf{1 4}$, and $\mathbf{1 5})$ and amides without a polar group (16 and 17) were synthesized by the procedures outlined in part B of Scheme 1. Coupling of adipic acid with 3-chloroaniline (for compound 6) or 1-adamantylamine (for compound 13) using 1-[3-(dimethylamino)propyl]-3-ethylcarbodiimide hydrochloride (EDCI) and 4-(dimethylamino)pyridine (DMAP) in dichloromethane, followed by alkylation of the acid with bromopentane in the presence of potassium carbonate $\left(\mathrm{K}_{2} \mathrm{CO}_{3}\right)$ as a base in dimethylformamide (DMF), yielded compounds 7 and 14, respectively, in $65 \%$ yield. ${ }^{19}$ As described in part B of Scheme 1,3-chlorophenylacetic acid (for compound 8), 1-adamantylacetic acid (for compound 14), or adamantane-1carboxylic acid (for compound 15) were coupled with ethyl 4-aminobutyrate hydrochloride in the presence of EDCI and DMAP in dichloromethane to give 3-chlorophenyl- or 1adamantylacetylaminobutyric acid ethyl ester intermediate (45\%), which was hydrolyzed with an aqueous solution of $1 \mathrm{~N} \mathrm{NaOH}$ in ethanol and then alkylated with bromopentane in the presence of $\mathrm{K}_{2} \mathrm{CO}_{3}$ as a base in DMF to afford compounds 8, 14, and 15 in 75-87\% yield. For preparation of $\mathbf{1 6}$ and 17, the same coupling reaction as described above (using EDCI and DMAP) was carried out from the corresponding starting materials (1-adamantanamine and dodecanoic acid for compound $\mathbf{1 6}$ (93\%), and adamantan-1-ylacetic acid and decylamine for compound $17(88 \%))$.

Compounds $\mathbf{9}, \mathbf{1 1}$, and $\mathbf{1 2}$ were synthesized by the procedures outlined in Scheme 2. Alkylation of succinic anhydride with pentanol and DMAP as a base in DMF, ${ }^{23}$ followed by reduction 
of carboxylic acid with $\mathrm{BH}_{3}$-THF complex in THF, provided 4-hydroxybutyric acid pentyl ester (I) in $85 \%$ yield. ${ }^{24}$ Reaction of $\mathbf{I}$ with 3-chlorophenyl isocyanate in DMF yielded $\mathbf{9}$, in $50 \%$ yield. I was also coupled with 3-chlorophenylacetic acid by using isobutyl chloroformate and triethylamine as a base to provide $\mathbf{1 1}(55 \%){ }^{25}$ Alkylation of I with 4-nitrophenyl chloroformate in the presence of triethylamine as a base in DMF gave 4-nitrophenyl carbonate intermediate (II)in 32\% yield, and reaction of II with 3-chlorophenol and $\mathrm{K}_{2} \mathrm{CO}_{3}$ as a base in acetonitrile provided $\mathbf{1 2}$ in $85 \%$ yield.

Scheme 3 shows synthesis of 4-(3-chlorophenoxycarbonylamino)butyric acid ethyl ester (10). Reaction of ethyl 4-aminobutyrate hydrochloride with triphosgene in $\mathrm{NaHCO}_{3}$ aqueous solution and dichloromethane gave 4-isocyanato intermediate III (95\%), ${ }^{26}$ which was alkylated with 3-chlorophenol in the presence of triethylamine in DMF to afford $\mathbf{1 0}(45 \%)$.

\section{Water Solubility $(S, \mu \mathrm{g} / \mathrm{mL})$}

Water solubility was determined experimentally using the following procedure at $25 \pm 1.5^{\circ} \mathrm{C}$. An excess of the test compound $(\mathbf{1}, \mathbf{4}, \mathbf{1 3}, \mathbf{1 4}, \mathbf{1 6}$, and $\mathbf{1 7}$ in Table 4) was added to a vial containing sodium phosphate buffer, $0.1 \mathrm{M}, \mathrm{pH} 7.4(1 \mathrm{~mL})$, and a suspension of the mixture was equilibrated during $1 \mathrm{~h}$ of sonication and $24 \mathrm{~h}$ of shaking, followed by centrifugation (5 min, $200 \mathrm{~g})$. The water supernatant $(2.5 \mu \mathrm{L})$ was dissolved in $0.5 \mathrm{~mL}$ of methanol, and to the methanol solution was added $0.5 \mathrm{~mL}$ of internal standard solution [1-cyclohexyl-3-

tetradecylurea (CTU); $1000 \mathrm{ng} / \mathrm{mL}$ in methanol]. A regression curve for each compound was obtained from five standard stock solutions $(r=0.99)$ by using LC-MS/MS [a Waters 2790 liquid chromatograph equipped with a $30 \times 2.1 \mathrm{~mm} 3 \mu \mathrm{m} \mathrm{C18} \mathrm{Xterra} \mathrm{column} \mathrm{(Waters)} \mathrm{and} \mathrm{a}$ Micromass Quattro Ultima triple quadrupole tandem mass spectrometer (Micromass, Manchester, UK)]. Then, the absolute amount of each compound was calculated. ${ }^{19,30}$

\section{Calculated Octanol/Water Partition Coefficients $(P)$ and Water Solubility (log $S)$}

The $\log P$ value estimated by Crippen's method was generated by using CS ChemDraw Ultra version 6.0. On the basis of this $\log P$ value, $\log S$ value (solubility in water) was also calculated with the following equation, which has been suggested by Banerjee et al.. ${ }^{29} \log P=6.5-0.89$ $(\log S)-0.015$ (melting point).

\section{Enzyme Preparation}

Recombinant murine $\mathrm{sEH}$ and human $\mathrm{sEH}$ were produced in a baculovirus expression system and purified by affinity chromatography. $31-33$ The preparations were at least $97 \%$ pure as judged by SDS-PAGE and scanning densitometry. No detectable esterase or glutathione transferase activities, which can interfere with this $\mathrm{SEH}$ assay, were observed. ${ }^{34}$ Protein concentration was quantified by using the Pierce BCA assay using fraction $\mathrm{V}$ bovine serum albumin (BSA) as the calibrating standard.

\section{$\mathrm{IC}_{50}$ Assay Conditions}

$\mathrm{IC}_{50}$ values were determined as described by using racemic 4-nitrophenyl-trans-2,3-epoxy-3phenylpropyl carbonate as substrate. ${ }^{34}$ Enzymes $(0.12 \mu \mathrm{M}$ mouse sEH or $0.24 \mu \mathrm{M}$ human $\mathrm{sEH})$ were incubated with inhibitors for $5 \mathrm{~min}$ in sodium phosphate buffer $(200 \mu \mathrm{L}), 0.1 \mathrm{M}$, $\mathrm{pH} 7.4$, containing $0.1 \mathrm{mg} / \mathrm{mL}$ of BSA, at $30^{\circ} \mathrm{C}$ before substrate introduction $([\mathrm{S}]=40 \mu \mathrm{M})$. Activity was assessed by measuring the appearance of the 4-nitrophenolate anion at $405 \mathrm{~nm}$ at $30{ }^{\circ} \mathrm{C}$ during $1 \mathrm{~min}$ (Spectramax $340 \mathrm{PC}$; Molecular Devices). Assays were performed in triplicate. $\mathrm{IC}_{50}$ is the concentration of inhibitor that reduces enzyme activity by $50 \%$ and was determined by regression of at least five datum points with a minimum of two points in the linear region of the curve on either side of the $\mathrm{IC}_{50}$. The curve was generated from at least three separate runs, each in triplicate, to obtain the standard deviation (SD) given in Tables 1-4. 


\section{Results and Discussion}

1,3-Disubstituted ureas with various alkyl, cycloalkyl, and aryl groups were reported as potent sEH inhibitors. ${ }^{16,18}$. 28 These urea inhibitors stabilize endogenous regulatory epoxides in several in vitro and in vivo models, resulting in the expected biological changes. $6,16,17$ However, the liphophilicity of 1,3-dialkylureas causes limited solubility in water, which probably affects their in vivo efficacy. ${ }^{18,19}$ In addition, the stability of the crystals of the urea compounds, indicated by their high melting point, led to a general lack of solubility, even in organic solvents. These poor physical properties of the 1,3-dialkylureas result in undesirable pharmacokinetic properties and difficulty in compound formulation in either an aqueous or oil base. ${ }^{19}$

Morisseau et al. ${ }^{18}$ showed that the addition of a polar functional group at the end of a long liphophilic aliphatic chain (12-13 atoms away from the urea function) of 1-(adamantan-1yl)-3-alkylureas makes compounds more hydrophilic while retaining their inhibitory potencies. We assume that such polar groups mimic the carboxylic acids of suspected endogenous substrates. Furthermore, we reported recently that urea compounds functionalized with a polar group (e.g. ester (1) or alcohol (2) in Table 1) located on the fifth atom from the urea carbonyl are as active as nonfunctionalized liphophilic inhibitor (4), and the resulting functionalized compounds show a 3 -fold better water solubility than the liphophilic inhibitor. As a following structure of compound $\mathbf{1}$, an ether derivative (3) with a polar group on the sixth atom has also the same inhibition as compounds $\mathbf{1}$ and $\mathbf{4}$, indicating that a polar group located on the fifth and/or sixth atom (Figure 1; termed herein as the secondary pharmacophore, with the urea moiety being the primary pharmacophore) from the urea carbonyl group is effective for preparing potent sEH inhibitors with improved water solubility. ${ }^{19}$ However, relatively high melting point and low water solubility still result in inhibitors that are difficult to formulate and show low bioavailability.

We previously reported that compounds with an amide functionality as the primary pharmacophore show potent inhibitory activity on murine and human sEHs, as well. ${ }^{3,18}$ As described in Table 2, the inhibitory potency $\left(\mathrm{IC}_{50}\right)$ of amide compounds disubstituted with liphophilic groups was observed in a range of $0.1-38 \mu \mathrm{M}$ with both enzymes, while the corresponding ureas showed inhibition $\left(\mathrm{IC}_{50}\right)$ in a range of $0.06-1.4 \mu \mathrm{M}$, implying that an amide functionality would be also useful in the synthesis of potent inhibitors. As shown in Table 2, a cyclohexylurea with a substitutent of 2-phenylethyl on the 3-position of the urea function (a-1) showed very potent inhibition with both murine and human enzymes. As the substitutent on the 3-position of the urea function of compound a-1 was replaced by 3chlorophenyl (b-1), 4-methoxyphenyl (c-1), and phenyl (d-1), the potencies were decreased by 2-20-fold on both enzymes. In the urea substituted with 2-hydroxymethylphenyl (e-1), no inhibition was obtained. Interestingly, when the urea functionality of compounds a-1, b-1, c-1, and d-1 was modified to the corresponding amides (a-d-2 and -3), 2-300-fold reduction in inhibition potency was also obtained as observed in urea inhibitors. In addition, the amides (e-2 and e-3) corresponding to the urea (e-1) with no inhibition had no inhibitory potency on either enzyme, suggesting that the SAR trend of amide inhibitors substituted with liphophilic groups was similar to that of ureas. Often, a high melting point, like the ones of ureas disubstutited with liphophilic groups, induces bad physical properties such as low solubility in water and organic solvents. ${ }^{19}$ The amide derivatives shown in Table 2 have lower melting points $\left(30-100^{\circ} \mathrm{C}\right)$ than the corresponding urea compounds, suggesting that functionalities such as amides will be worth examining as the primary pharmacophore to develop potent inhibitors with improved physical properties.

Therefore, to further improve the physical properties of previously reported urea inhibitors, we investigated the effect of structural modification of the urea functionality with amide, 
carbamate, ester, and carbonate derivatives, as shown in Table 3. Compounds with a 3chlorophenyl group on one side (5-12 in Table 3) were first synthesized, because the ultraviolet-dense aromatic group simplifies monitoring their formation and purification, and the corresponding ureas are relatively good sEH inhibitors (5 and $\mathbf{6})$. After optimizing the primary pharmacophore, the aryl substitutent can be replaced by an adamantyl group, leading to more potent but generally UV-transparent inhibitors. In general, 3-chlorophenyl derivatives are $2-5$-fold less potent than adamantyl derivatives with the recombinant murine and human enzymes. ${ }^{16}$ In addition, it was shown in the previous study that an ester (5), alcohol (6), or ketone located on the fifth atom from the primary urea carbonyl group is a good functionality for the secondary pharmacophore and that among these functionalities the ester functional group can be prepared easily and in a higher yield than the alcohol or ketone. Therefore, the ester functionality was maintained as the secondary pharmacophore in the present study (Table $3)$. The replacement of the urea function (5) by an amide function ( $\mathbf{7}$ and $\mathbf{8})$ results in 5-fold loss of inhibition potency for the murine sEH and a 2-fold loss for the human enzyme. Interestingly, for compounds without a secondary pharmacophore, at least a 20-fold lower inhibition was observed for amides compared to the corresponding urea inhibitor, ${ }^{18}$ underlying the positive effect on inhibitor binding of the secondary pharmacophore. The presence of the nitrogen atom at the left side of the carbonyl group of the amide (7) induced 1.5 -fold better inhibition than at the right position (8) for the murine sEH, while for the human sEH no change in the potency was observed between these two amides. The presence of oxygen to the right side of carbonyl group, yielding carbamate (9), dropped the activity by 10 -fold, and interestingly, in the carbamate (10) with the oxygen in the left of the carbonyl, no inhibition was observed, confirming that a nitrogen atom $(\mathrm{N}-\mathrm{H})$ on the left side of the carbonyl group is important for potent inhibition in this series. Replacement of the carbamate nitrogen on the right side of the carbonyl of compound 9 by a methylene carbon (ester, 11) resulted in total loss of inhibition for both murine and human sEHs. Moreover, the structure with two oxygen atoms on both sides of the carbonyl group (carbonate, 12) showed no inhibition, confirming that the presence of at least one nitrogen atom $(\mathrm{N}-\mathrm{H})$ in the primary pharmacophore is essential for inhibiting sEHs. These results overall agreed with previous observation by Morisseau et al. that at least one free amine $(\mathrm{N}-\mathrm{H})$ of the urea function is necessary for the inhibition potency. 16

The data in Table 3 indicate that the best functionality for direct inhibition of pure sEH for the primary pharmacophore is a urea ( $\mathbf{5}$ and $\mathbf{6})$; however, good inhibition was obtained with amides (7 and 8). So the amide functionality was maintained as primary pharmacophore, and the 3chlorophenyl group on the left side of the amide function was then replaced by a potent adamantyl group. As shown in Table 4, the adamantyl substitution on the left side of the amide pharmacophore increased inhibitor potency 2-50-fold (13 and 14) over that of the 3-

chlorophenyl analogue ( $\mathbf{7}$ and $\mathbf{8}$ ) for both enzymes, indicating that a bulky cycloalkyl group is a more efficient substituent of the amide pharmacophore than an aryl group for inducing potent inhibition, which is consistent with previous results obtained for urea derivatives. ${ }^{19}$ A nitrogen atom present on the right side of the carbonyl of the amide function (14) produced 10- and 5fold better inhibition on murine and human sEHs, respectively, than that on the left side of the carbonyl group (13). Similarly, the right side nitrogen atom in the liphophilic amide analogue (17) induced 50-fold better inhibition on human sEH than the nitrogen atom on the left side of carbonyl group (16), while no change in inhibition potency on the murine sEH was observed with either compound (16 and 17). On the other hand, in compounds with a cyclohexyl group on one side of the amide function in Table 2 and compounds $\mathbf{6}$ and $\mathbf{7}$ substituted with a 3chlorophenyl group, no reasonable changes in the inhibition potency between the amide functions as that shown in adamantyl derivatives $(\mathbf{1 3}, \mathbf{1 4}, \mathbf{1 6}$, and 17) were obtained, suggesting that a bulky adamantyl group makes a nitrogen atom present on the right side of the amide function more optimal for producing potent inhibition than the left side nitrogen atom. Interestingly, the same inhibition potency as observed for urea $\mathbf{1}$ was obtained for amide $\mathbf{1 4}$ 
for the murine sEH, while for the human sEH a 2.5-fold lower inhibition was observed for the amide inhibitor (14) over the urea analogue (1). Furthermore, the activities obtained for compounds $\mathbf{1 4}$ and $\mathbf{1}$ are as potent as the enzyme inhibition observed for the liphophilic urea 4, suggesting that structural modifications of the urea primary pharmacophore can be effective in producing potent inhibitors for murine and human enzymes in the presence of a secondary pharmacophore. In addition, the amide function of compound 15, without a methylene carbon between the adamantane and amide groups, dropped the inhibition 50- and 20-fold for murine and human sEHs, respectively, implying that a methylene carbon present between those groups is important to make the amide inhibitors potent.

The water solubility of these inhibitors was experimentally measured (Table 4). Around 10fold better solubility was obtained for compounds $\mathbf{1 3}$ and $\mathbf{1 4}$ with the amide primary pharmacophore than with the urea functionality (1). However, no improvement in water solubility was observed in nonfunctionalized compounds with the amide primary pharmacophore (16 and 17) compared to the corresponding urea (4). When integrated, these results indicate that a big improvement in water solubility can be gained when the liphophilic tail is functionalized with the secondary pharmacophore and when the primary pharmacophore is an amide. As expected, decreased $\log P$ values ( $\sim 3)$ and much lower melting points (oils) were obtained in the functionalized amide inhibitors (13 and 14), indicating that the amide function of substituted inhibitors improved solubility in water and that the calculated $\log P$ values and melting points are useful factors to estimate water solubility, which is a result consistent with that previously reported in our lab. ${ }^{19}$ The $\log P$ values of neutral immiscible liquids generally run parallel with their water solubility; however, estimating solubility of solids is complex, because it depends on the energy required to break the crystal lattice. Banerjee et al. have suggested an empirical equation $[\log P=6.5-0.89(\log S)-0.015 \mathrm{mp}]$ to relate solubility, melting point (mp), and $\log P$ : it is possible to have compounds with high $\log$ $P$ values that are still relatively soluble because of their low melting point. Similarly, it is possible to have a low $\log P$ compound with a high melting point that is very insoluble in both aqueous and organic solutions. ${ }^{29}$ As shown in Table 4, a 10-fold increase in calculated water solubility $(\log S)$, which was determined according to the above equation, was obtained in functionalized amide inhibitors (13 and 14) compared to the corresponding urea (1), which was consistent with the solubility obtained experimentally. However, consistency between calculated and experimentally determined solubility was not observed for the higher melting compounds lacking the secondary pharmacophore. These data suggest that Banerjee's equation might be limited to estimating the water solubility of more polar compounds with lower melting points.

This investigation was directed toward producing potent sEH inhibitors with improved physical properties (e.g. solubilities and melting points). We found that no loss of inhibition potency for sEHs was observed when the urea primary pharmacophore was replaced with an amide functionality, as long as an ester secondary pharmacophore is present on the fifth atom from the carbonyl of the primary pharmacophore. Under these conditions for the primary pharmacophore, a 10- and 5-fold better inhibition of murine and human sEHs, respectively, is obtained if the nitrogen of the amide function is placed on the right of the carbonyl. Furthermore, the presence of a methylene carbon between the amide function and a bulky cycloalkyl group (compound 14) is essential to produce potent amide inhibitors. In addition, the resulting amide inhibitors had 10-30-fold better solubility in water and lower melting point than the corresponding urea compounds. Also in general there is a predictive correlation between the structure-activity relationships (SARs) among compounds with a urea and amide central pharmacophore. The ester derivatives at the secondary pharmacophore provide a facile synthetic route to exploring the steric and electronic effects of the right distal structural components on enzyme binding. However, it is likely that an unhindered ester would be too unstable in vivo to give effective blood levels. However, such compounds may prove valuable 
as soft drugs that can be administered directly to the target tissue such as skin, air way, or intestinal mucosa. These findings are important for the design of potent inhibitors with improved physical properties that will lead to obtaining intravenous or orally available therapeutic agents for hypertension, inflammation, and other disorders that can be addressed by changing the in vivo concentration of chemical mediators that contain an epoxide.

\section{Experimental Section}

\section{Syntheses}

All melting points were determined with a Thomas-Hoover apparatus (A. H. Thomas Co.) and are uncorrected. Mass spectra were measured by LC-MS/MS (Waters 2790) using positive mode electrospray ionization. Elemental analyses $(\mathrm{C}, \mathrm{H} / \mathrm{N})$ were performed by Midwest Microlab, IN; analytical results were within $\pm 0.4 \%$ of the theoretical values for the formula given unless otherwise indicated. ${ }^{1} \mathrm{H}$ NMR spectra were recorded on a QE-300 spectrometer, using tetramethylsilane as an internal standard. Signal multiplicities are represented as singlet (s), doublet (d), double doublet (dd), triplet (t), quartet (q), quintet (quint), multiplet (m), broad (br), and broad singlet (brs). Synthetic methods are described for representative compounds.

\section{5-(3-Chlorophenylcarbamoyl)pentanoic Acid Pentyl Ester (7)}

To a solution of adipic acid ( $0.5 \mathrm{~g}, 3.42 \mathrm{mmol})$ and DMAP $(0.42 \mathrm{~g}, 3.42 \mathrm{mmol})$ in dichloromethane $(30 \mathrm{~mL})$ and DMF $(3 \mathrm{~mL})$ was added 3-chloroaniline $(0.44 \mathrm{~g}, 3.42 \mathrm{mmol})$ at room temperature. After stirring $10 \mathrm{~min}, 1$-[3-(dimethylamino)-propyl]-3-ethylcarbodiimide hydrochloride $(0.65 \mathrm{~g}, 3.42 \mathrm{mmol}$; EDCI) was added portionwise to the mixture at room temperature. The reaction was stirred for $12 \mathrm{~h}$. A $1 \mathrm{~N}$ aqueous $\mathrm{HCl}$ solution $(20 \mathrm{~mL})$ was poured into the reaction mixture, and 5-(3-chlorophenylcarbomoyl)pentanoic acid was extracted with dichloromethane $(30 \mathrm{~mL})$. The organic solution was washed with water $(50 \mathrm{~mL})$, dried over $\mathrm{Na}_{2} \mathrm{SO}_{4}$, and concentrated. This residue was used for the next reaction without further purification.

To the solution of the above carbamoylpentanoic acid $(0.72 \mathrm{~g}, 2.80 \mathrm{mmol})$ in DMF (15 $\mathrm{mL})$ was added $\mathrm{K}_{2} \mathrm{CO}_{3}(0.58 \mathrm{~g}, 4.21 \mathrm{mmol})$ and 1-bromopentane $(0.64 \mathrm{~g}, 4.21 \mathrm{mmol})$ at room temperature. After stirring for $12 \mathrm{~h}$, the product was extracted with ether $(30 \mathrm{~mL})$, and the ether solution was washed with an aqueous solution of $1 \mathrm{~N} \mathrm{NaOH}(15 \mathrm{~mL})$ and water $(40 \mathrm{~mL})$, dried over $\mathrm{Na}_{2} \mathrm{SO}_{4}$, and concentrated. The residue was purified using silica gel column chromatography (hexane:ethyl acetate $=5: 1)$ to afford $7(0.59 \mathrm{~g}, 65 \%):{ }^{1} \mathrm{H} \mathrm{NMR} \delta\left(\mathrm{CDCl}_{3}\right)$ $0.91(3 \mathrm{H}, \mathrm{t}, J=6.9 \mathrm{~Hz}), 1.29-1.37(4 \mathrm{H}, \mathrm{m}), 1.60-1.66(2 \mathrm{H}, \mathrm{m}), 1.70-1.78(4 \mathrm{H}, \mathrm{m}), 2.35-2.43$ $(4 \mathrm{H}, \mathrm{m}), 4.08(\mathrm{H}, \mathrm{t}, J-6.9 \mathrm{~Hz}), 7.05-7.09(1 \mathrm{H}, \mathrm{m}), 7.21-7.23(1 \mathrm{H}, \mathrm{m}), 7.37-7.40(1 \mathrm{H}, \mathrm{m})$, 7.52-7.55 (1H, m), $7.68(1 \mathrm{H}, \mathrm{s})$; LC-MS (ESI) $\mathrm{m} / z$ calcd for $\mathrm{C}_{17} \mathrm{H}_{24} \mathrm{ClNO}_{3}[\mathrm{M}+\mathrm{H}]^{+} 326.14$, found $[\mathrm{M}+\mathrm{H}]^{+} 326.16$, mp $82{ }^{\circ} \mathrm{C}$. Anal. $\left(\mathrm{C}_{17} \mathrm{H}_{24} \mathrm{ClNO}_{3}\right) \mathrm{C}, \mathrm{H}, \mathrm{N}$.

Compound 13 was prepared with the same method used for the preparation of compound 7 using adamantylamine instead of 3-chloroaniline: ${ }^{1} \mathrm{H} \mathrm{NMR} \delta\left(\mathrm{CDCl}_{3}\right) 0.91(3 \mathrm{H}, \mathrm{t}, J=6.9 \mathrm{~Hz})$, 1.29-1.43 (4H, m), 1.64-1.69 (12H, m), 1.94-1.98 (6H, m), 2.06-2.13 (5H, m), $2.32(2 \mathrm{H}, \mathrm{t}$, $J=6.9 \mathrm{~Hz}), 4.06(\mathrm{H}, \mathrm{t}, J=6.9 \mathrm{~Hz}), 5.16(1 \mathrm{H}, \mathrm{s}) ; \mathrm{LC}-\mathrm{MS}(\mathrm{ESI}) \mathrm{m} / z$ calcd for $\mathrm{C}_{21} \mathrm{H}_{35} \mathrm{NO}_{3}[\mathrm{M}$ $+\mathrm{H}]^{+}$350.26, found $[\mathrm{M}+\mathrm{H}]^{+}$350.30. Anal. $\left(\mathrm{C}_{21} \mathrm{H}_{35} \mathrm{NO}_{3}\right) \mathrm{C}, \mathrm{H}, \mathrm{N}$.

\section{4-[2-(3-Chlorophenyl)acetylamino]butyric Acid Pentyl Ester (8)}

To a solution of 3-chlorophenylacetic acid $(0.5 \mathrm{~g}, 2.93 \mathrm{mmol})$ and DMAP $(0.36 \mathrm{~g}, 2.93 \mathrm{mmol})$ in dichloromethane $(30 \mathrm{~mL})$ was added ethyl 4-aminobutyrate hydrochloride $(0.49 \mathrm{~g}, 2.93$ $\mathrm{mmol})$ at room temperature. After stirring for $10 \mathrm{~min}$, EDCI $(0.56 \mathrm{~g}, 2.93 \mathrm{mmol})$ was added portionwise to the mixture at room temperature. The reaction was stirred for $12 \mathrm{~h}$. A $1 \mathrm{~N}$ aqueous $\mathrm{HCl}$ solution $(20 \mathrm{~mL})$ was poured into the reaction mixture, and 4-[2-(3-chlorophenyl) 
acetylamino]butyric acid ethyl ester was extracted with ether $(30 \mathrm{~mL})$. The ether solution was washed with water $(50 \mathrm{~mL})$, dried over $\mathrm{Na}_{2} \mathrm{SO}_{4}$, and concentrated. To the residue dissolved in ethanol $(10 \mathrm{~mL})$ was added $1 \mathrm{~N}$ aqueous $\mathrm{NaOH}$ solution $(6 \mathrm{~mL})$, and after $12 \mathrm{~h}$ of stirring at room temperature, the product was extracted with dichloromethane $(30 \mathrm{~mL})$. The organic solution was washed with water $(30 \mathrm{~mL})$, dried over $\mathrm{Na}_{2} \mathrm{SO}_{4}$, and concentrated to give 4-[2(3-chlorophenyl)acetylamino]butyric acid $(0.6 \mathrm{~g}, 80 \%)$. A mixture of this acid $(0.6 \mathrm{~g}, 2.35$ $\mathrm{mmol}), \mathrm{K}_{2} \mathrm{CO}_{3}(0.49 \mathrm{~g}, 3.52 \mathrm{mmol})$, and 1-bromopentane (0.53 g, $\left.3.52 \mathrm{mmol}\right)$ in DMF (20 $\mathrm{mL}$ ) was stirred overnight at room temperature. The product was extracted with ether $(40 \mathrm{~mL})$, and the ether solution was washed with water $(50 \mathrm{~mL})$, dried over $\mathrm{Na}_{2} \mathrm{SO}_{4}$, and concentrated. The residue was purified using silica gel column chromatography (hexane:ethyl acetate $=3: 1$ ) to afford 8 as an oil $(0.74 \mathrm{~g}, 97 \%):{ }^{1} \mathrm{H}$ NMR $\delta\left(\mathrm{CDCl}_{3}\right) 0.91(3 \mathrm{H}, \mathrm{t}, J=6.9 \mathrm{~Hz}), 1.26-1.33$ $(4 \mathrm{H}, \mathrm{m}), 1.59-1.63(2 \mathrm{H}, \mathrm{m}), 1.80(2 \mathrm{H}$, quint, $J=6.9 \mathrm{~Hz}), 2.31(2 \mathrm{H}, \mathrm{t}, J=6.9 \mathrm{~Hz}), 3.27(2 \mathrm{H}$, $\mathrm{q}, J=6.9 \mathrm{~Hz}), 3.52(2 \mathrm{H}, \mathrm{s}), 4.04(2 \mathrm{H}, \mathrm{t}, J=6.9 \mathrm{~Hz}), 5.72(1 \mathrm{H}, \mathrm{s}), 7.13-7.17(2 \mathrm{H}, \mathrm{m}), 7.27-$ $7.30(2 \mathrm{H}, \mathrm{m})$; LC-MS (ESI) $\mathrm{m} / \mathrm{z}$ calcd for $\mathrm{C}_{17} \mathrm{H}_{24} \mathrm{ClNO}_{3}[\mathrm{M}+\mathrm{H}]^{+} 326.14$, found $[\mathrm{M}+\mathrm{H}]^{+}$ 326.15. Anal. $\left(\mathrm{C}_{17} \mathrm{H}_{24} \mathrm{ClNO}_{3}\right) \mathrm{C}, \mathrm{H}, \mathrm{N}$.

Compounds 14 and 15 were prepared with the same method used for the preparation of compound 8 using 1-adamantylacetic acid or adamantane-1-carboxylic acid instead of 3chlorophenylacetic acid. Compound 14: ${ }^{1} \mathrm{H}$ NMR $\delta\left(\mathrm{CDCl}_{3}\right) 0.91(3 \mathrm{H}, \mathrm{t}, J=6.9 \mathrm{~Hz}), 1.29$ $1.35(4 \mathrm{H}, \mathrm{m}), 1.35-1.72(14 \mathrm{H}, \mathrm{m}), 1.84(2 \mathrm{H}$, quint, $J=6.9 \mathrm{~Hz}), 1.91(2 \mathrm{H}, \mathrm{s}), 1.97(3 \mathrm{H}, \mathrm{m})$, $2.37(2 \mathrm{H}, \mathrm{t}, J=6.9 \mathrm{~Hz}), 3.29(2 \mathrm{H}, \mathrm{q}, J=6.9 \mathrm{~Hz}), 4.07(2 \mathrm{H}, \mathrm{t}, J=6.9 \mathrm{~Hz}), 5.66(1 \mathrm{H}, \mathrm{s}) ; \mathrm{LC}-$ MS (ESI) $\mathrm{m} / z$ calcd for $\mathrm{C}_{21} \mathrm{H}_{35} \mathrm{NO}_{3}[\mathrm{M}+\mathrm{H}]^{+} 350.26$, found $[\mathrm{M}+\mathrm{H}]^{+}$350.29. Anal. $\left(\mathrm{C}_{21} \mathrm{H}_{35} \mathrm{NO}_{3}\right) \mathrm{C}, \mathrm{H}, \mathrm{N}$.

Compound 15: ${ }^{1} \mathrm{H}$ NMR $\delta\left(\mathrm{CDCl}_{3}\right) 0.91(3 \mathrm{H}, \mathrm{t}, J=6.9 \mathrm{~Hz}), 1.29-1.35(4 \mathrm{H}, \mathrm{m}), 1.60-1.86$ $(16 \mathrm{H}, \mathrm{m}), 2.03(3 \mathrm{H}, \mathrm{m}), 2.35(2 \mathrm{H}, \mathrm{t}, J=6.9 \mathrm{~Hz}), 3.29(2 \mathrm{H}, \mathrm{q}, J=6.9 \mathrm{~Hz}), 4.07(2 \mathrm{H}, \mathrm{t}, J=6.9$ $\mathrm{Hz}$ ), $5.85(1 \mathrm{H}, \mathrm{s})$; LC-MS (ESI) $\mathrm{m} / z$ calcd for $\mathrm{C}_{20} \mathrm{H}_{33} \mathrm{NO}_{3}[\mathrm{M}+\mathrm{H}]^{+} 336.25$, found $[\mathrm{M}+$ $\mathrm{H}]^{+}$336.34. Anal. $\left(\mathrm{C}_{20} \mathrm{H}_{33} \mathrm{NO}_{3}\right) \mathrm{C}, \mathrm{H}, \mathrm{N}$.

\section{4-(3-Chlorophenylcarbamoyloxy)butyric Acid Pentyl Ester (9)}

To a solution of succinic anhydride $(3.58 \mathrm{~g}, 35.7 \mathrm{mmol})$ and DMAP $(4.16 \mathrm{~g}, 34.0 \mathrm{mmol})$ in DMF $(40 \mathrm{~mL})$ was added pentanol $(3.0 \mathrm{~g}, 34.0 \mathrm{mmol})$ at room temperature under nitrogen. After stirring for $12 \mathrm{~h}$, succinic acid pentyl ester was extracted with ether $(40 \mathrm{~mL})$, and the ether solution was washed with $1 \mathrm{~N}$ aqueous $\mathrm{HCl}$ solution $(20 \mathrm{~mL})$ and water $(40 \mathrm{~mL})$, dried over sodium sulfate $\left(\mathrm{Na}_{2} \mathrm{SO}_{4}\right)$, and concentrated. The residue was purified by column chromatography on silica gel eluting with hexane and ethyl acetate (3:1) to give the succinic acid pentyl ester $(6.07 \mathrm{~g}, 95 \%)$ as an oil. To the solution of this acid in tetrahydrofuran (THF, $60 \mathrm{~mL})$ was added $1 \mathrm{M} \mathrm{BH}_{3}-\mathrm{THF}$ complex $(64.53 \mathrm{~mL}, 64.5 \mathrm{mmol})$ at $-10^{\circ} \mathrm{C}$ under nitrogen, and the reaction mixture was allowed to warm to room temperature with stirring. After stirring for $12 \mathrm{~h}$ at room temperature, $5 \% \mathrm{NaHCO}_{3}$ aqueous solution $(50 \mathrm{~mL})$ was added to the reaction and then the reduced alcohol (I) was extracted with ethyl acetate $(50 \mathrm{~mL})$. The ethyl acetate solution was dried over $\mathrm{Na}_{2} \mathrm{SO}_{4}$ and concentrated to give $\mathbf{I}(5.06 \mathrm{~g}, 90 \%)$.

4-Hydroxybutyric acid pentyl ester (I; $100 \mathrm{mg}, 0.57 \mathrm{mmol}$ ) was added to a solution of 3chlorophenyl isocyanate $(88 \mathrm{mg}, 0.57 \mathrm{mmol})$ and triethylamine $(0.12 \mathrm{~mL}, 0.86 \mathrm{mmol}$; TEA) in DMF $(15 \mathrm{~mL})$ at room temperature. The mixture was allowed to stand at room temperature for $12 \mathrm{~h}$, the product was extracted with ether $(20 \mathrm{~mL})$, and the ether solution was washed with $1 \mathrm{~N}$ aqueous $\mathrm{HCl}$ solution $(20 \mathrm{~mL})$ and water $(30 \mathrm{~mL})$, dried over $\mathrm{Na}_{2} \mathrm{SO}_{4}$, and concentrated. The residue was purified by column chromatography on silica gel eluting with hexane and ethyl acetate (5:1) to afford $\mathbf{9}(94 \mathrm{mg}, 50 \%)$ as a solid: ${ }^{1} \mathrm{H} \mathrm{NMR} \delta\left(\mathrm{CDCl}_{3}\right) 0.90(3 \mathrm{H}, \mathrm{t}, J=6.9$ $\mathrm{Hz}), 1.26-1.34(4 \mathrm{H}, \mathrm{m}), 1.62-1.65(2 \mathrm{H}, \mathrm{m}), 1.71(2 \mathrm{H}$, quint, $J=6.9 \mathrm{~Hz}), 2.66(2 \mathrm{H}, \mathrm{t}, J=6.9$ $\mathrm{Hz}), 2.74(2 \mathrm{H}, \mathrm{q}, J=6.9 \mathrm{~Hz}), 4.10(2 \mathrm{H}, \mathrm{t}, J=6.9 \mathrm{~Hz}), 7.05-7.08(1 \mathrm{H}, \mathrm{m}), 7.18-7.22(3 \mathrm{H}, \mathrm{m})$, 
$7.35(1 \mathrm{H}, \mathrm{s})$; LC-MS (ESI) $\mathrm{m} / z$ calcd for $\mathrm{C}_{16} \mathrm{H}_{22} \mathrm{ClNO}_{4}[\mathrm{M}+\mathrm{H}]^{+} 328.12$, found $[\mathrm{M}+\mathrm{H}]^{+}$

$328.13 ; \mathrm{mp} 82{ }^{\circ} \mathrm{C}$. Anal. $\left(\mathrm{C}_{16} \mathrm{H}_{22} \mathrm{ClNO}_{4}\right) \mathrm{C}, \mathrm{H}, \mathrm{N}$.

Acknowledgment

This work was supported, in part, by NIEHS Grant R37 ES02710, NIEHS Center for Environmental Health Sciences P30 ES05707, NIH/NIEHS Superfund Basic Research Program P42 ES-04699, NIH/NHLBI R01 HL59699-06A1, UC Systemwide Biotechnology Research and Education Training Grant \#2001-07, NIEHS Center for Children's Environmental Health \& Disease Prevention P01 ES11269, and NIH/NIDDK UC Davis Clinical Nutrition Research Unit P30 DK35747, Pilot Project.

\section{References}

1. Zeldin DC, Kobayashi J, Falck JR, Winder BS, Hammock BD, Snapper JR, Capdevila JH. Regio- and enantiofacial selectivity of epoxyeicosatrienoic acid hydration by cytosolic epoxide hydrolase. J. Biol. Chem 1993;268:6402-6407. [PubMed: 8454612]

2. Moghaddam MF, Grant DF, Cheek JM, Greene JF, Williamson KC, Hammock BD. Bioactivation of leukotoxins to their toxic diols by epoxide hydrolase. Nat. Med 1997;3:562-567. [PubMed: 9142128]

3. Carroll MA, McGiff JC. A new class of lipid mediators: Cytochrome P450 arachidonate metabolites. Thorax 2000;55:S13-16. [PubMed: 10992547]

4. Capdevila JH, Falck JR, Harris RC. Cytochrome P450 and arachidonic acid bioactivation: Molecular and functional properties on the arachidonate monooxygenase. J. Lipid Res 2000;41:163-181. [PubMed: 10681399]

5. Yu Z, Xu F, Huse LM, Morisseau C, Draper AJ, Newman JW, Parker C, Graham L, Engler MM, Hammock BD, Zeldin DC, Kroetz DL. Soluble epoxide hydrolase regulates hydrolysis of vasoactive epoxyeicosatrienoic acids. Circ. Res 2000;87:992-998. [PubMed: 11090543]

6. Imig JD, Zhao X, Capdevila JH, Morisseau C, Hammock BD. Soluble epoxide hydrolase inhibition lowers arterial blood pressure in angiotensin II hypertension. Hypertension 2002;39:690-694. [PubMed: 11882632]

7. Zhao X, Yamamoto T, Newman JW, Kim IH, Watanabe T, Hammock BD, Stewart J, Pollock JS, Pollock DM, Imig JD. Soluble epoxide hydrolase inhibition protects the kidney from hypertensioninduced damage. J. Am. Soc. Nephrol 2004;15:1244-1253. [PubMed: 15100364]

8. Sinal CJ, Miyata M, Tohkin M, Nagata K, Bend JR, Gonzalez FJ. Targeted disruption of soluble epoxide hydrolase reveals a role in blood pressure regulation. J. Biol. Chem 2000;275:40504-40510. [PubMed: 11001943]

9. Oltman CL, Weintraub NL, VanRollins M, Dellsperger KC. Epoxyeicosatrienoic acids and dihydroxyeicosatrienoic acids are potent vasodilators in the canine coronary microcirculation. Circ. Res 1998;83:932-939. [PubMed: 9797342]

10. Fisslthaler B, Popp R, Kiss L, Potente M, Harder DR, Fleming I, Busse R. Cytochrome P450 2C is an EDHF synthase in coronary arteries. Nature 1999;401:493-497. [PubMed: 10519554]

11. Node K, Huo Y, Ruan X, Yang B, Spiecker M, Ley K, Zeldin DC, Liao JK. Antiinflammatory properties of cytochrome P450 epoxygenase-derived eicosanoids. Science 1999;285:1276-1279. [PubMed: 10455056]

12. Campbell WB. New role for epoxyeicosatrienoic acids as antiinflammatory mediators. Trends Pharmacol. Sci 2000;21:125-127. [PubMed: 10740283]

13. Yang B, Graham L, Dikalov S, Mason RP, Falck JR, Liao JK, Zeldin DC. Overexpression of cytochrome P450 CYP2J2 protects against hypoxia-reoxygenation injury in cultured bovine aortic endothelial cells. Mol. Pharmacol 2001;60:310-320. [PubMed: 11455018]

14. Sun J, Sui X, Bradbury JA, Zeldin DC, Conte MS, Liao JK. Inhibition of vascular smooth muscle cell migration by cytochrome P450 epoxygenase-derived eicosanoids. Circ. Res 2002;90:1020-1027. [PubMed: 12016269]

15. Node K, Ruan X, Dai J, Yang S, Graham L, Zeldin DC, Liao JK. Activation of Gs mediates induction of tissue-type plasminogen activator gene transcription by epoxyeicosatrienoic acids. J. Biol. Chem 2001;276:15983-15989. [PubMed: 11279071] 
16. Morisseau C, Goodrow MH, Dowdy D, Zheng J, Greene JF, Sanborn JR, Hammock BD. Potent urea and carbamate inhibitors of soluble epoxide hydrolases. Proc. Natl. Acad. Sci. U.S.A. 1999;96:88498854. [PubMed: 10430859]

17. Newman JW, Denton DL, Morisseau C, Koger CS, Wheelock CE, Hinton DE, Hammock BD. Evaluation of fish models of soluble epoxide hydrolase inhibition. Environ. Health Perspect 2001;109:61-66. [PubMed: 11171526]

18. Morisseau C, Goodrow MH, Newman JW, Wheelock CE, Dowdy DL, Hammock BD. Structural refinement of inhibitors of urea-based soluble epoxide hydrolases. Biochem. Pharmacol 2002;63:1599-1608. [PubMed: 12007563]

19. Kim IH, Morisseau C, Watanabe T, Hammock BD. Design, synthesis, and biological activity of 1,3disubstituted ureas as potent inhibitors of the soluble epoxide hydrolase of increased water solubility. J. Med. Chem 2004;47:2110-2122. [PubMed: 15056008]

20. Argiriadi MA, Morisseau C, Hammock BD, Christianson, DW. Detoxification of environmental mutagens and carcinogens: Structure, mechanism, and evolution of liver epoxide hydrolase. Proc. Natl. Acad. Sci. U.S.A 1999;96:10637-10642. [PubMed: 10485878]

21. Argiriadi MA, Morisseau C, Goodrow MH, Dowdy DL, Hammock BD, Christianson DW. Binding of alkylurea inhibitiors to epoxide hydrolase implicates active site tyrosines in substrate activation. J. Biol. Chem 2000;275:15265-15270. [PubMed: 10747889]

22. Dhaon MK, Olsen RK, Ramasamy K. Esterification of N-protected alpha-amino acids with alcohol/ carbodiimide/4-(dimethylamino)pyridine. Racemization of aspartic and glutamic acid derivatives. J. Org. Chem 1982;47:1962-1965.

23. Larsen SD, Barf T, Liljebris C, May PD, Ogg D, O'Sullivan TJ, Palazuk BJ, Schostarez HJ, Stevens FC, Bleasdale JE. Synthesis and biological Activity of a novel class of small molecular weight peptidomimetic competitive inhibitors of protein tyrosine phosphatase 1B. J. Med. Chem 2002;45:598-622. [PubMed: 11806712]

24. Yoon NM, Cho BT. Rapid reduction of carboxylic acid salts with borane in tetrahydrofuran. Tetrahedron Lett 1982;23:2475-2478.

25. Balboni G, Guerrini R, Salvadori S, Bianchi C, Rizzi D, Bryant SD, Lazarus LH. Evaluation of the Dmt-Tic pharmacophore: Conversion of a potent $\delta$-opioid receptor antagonist into a potent $\delta$ agonist and ligands with mixed properties. J. Med. Chem 2002;45:713-720. [PubMed: 11806723]

26. Weisenfeld RB. Synthesis of disiloxanediyl diamines via a facile homocondensation of amino silanols. J. Org. Chem 1986;51:2434-2436.

27. Ellison RA, Lukenbach ER, Chiu C. Cyclopentenone synthesis via aldol condensation. Synthesis of a key prostaglandin intermediate. Tetrahedron Lett 1975;16:499-502.

28. McElroy NR, Jurs PC, Morisseau C, Hammock BD. QSAR and classification of murine and human soluble epoxide hydrolase inhibition by urea-like compounds. J. Med. Chem 2003;46:1066-1080. [PubMed: 12620084]

29. Banerjee S, Yalkowsky SH, Valvani SC. Water solubility and octanol/water partition coefficients of organics. Limitations of the solubility-partition coefficient correlation. Environ. Sci. Technol 1980;10:1227-1229.

30. Watanabe T, Hammock BD. Rapid determination of soluble epoxide hydrolase inhibitors in rat hepatic microsomes by high-performance liquid chromatography with electrospray tandem mass spectrometry. Anal. Biochem 2001;299:227-234. [PubMed: 11730347]

31. Grant DE, Storms DH, Hammock BD. Molecular cloning and expression of murine liver soluble epoxide hydrolase. J. Biol. Chem 1993;268:17628-17633. [PubMed: 8349642]

32. Beetham JK, Tian T, Hammock BD. cDNA cloning and expression of a soluble epoxide hydrolase from human liver. Arch. Biochem. Biophys 1993;305:197-201. [PubMed: 8342951]

33. Wixtrom RN, Silva MH, Hammock BD. Affinity purification of cytosolic epoxide hydrolase using derivatized epoxy-activated Sepharose gels. Anal. Biochem 1998;169:71-80. [PubMed: 3369689]

34. Dietze EC, Kuwano E, Hammock BD. Spectrophotometric substrates for cytosolic epoxide hydrolase. Anal. Biochem 1994;216:176-187. [PubMed: 8135350] 


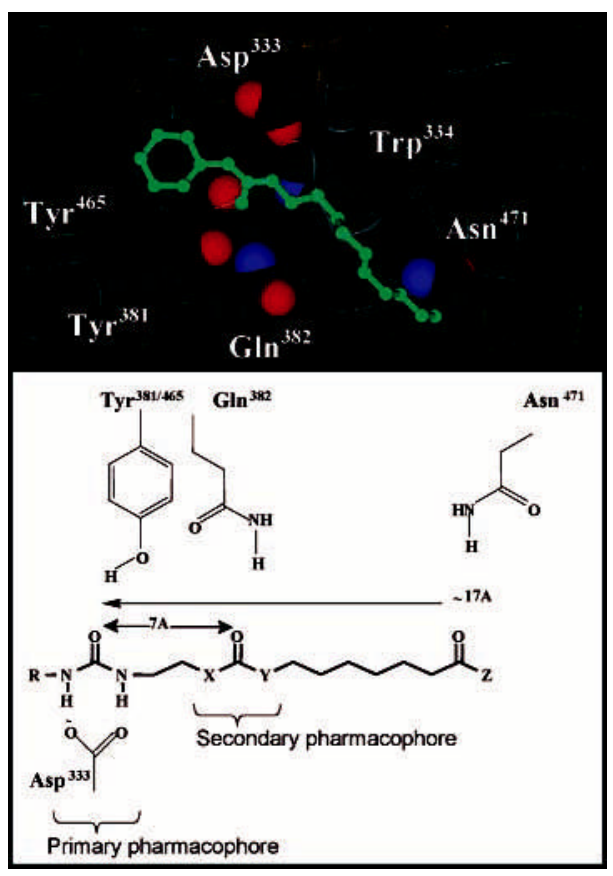

Figure 1.

Diagram of the murine sEH active site and a sEH inhibitor: Distance of potential binding interaction from primary urea pharmacophore. The primary pharmacophore consistents of a polar carbonyl group, shown in this case as a urea with $\mathrm{R}=$ cyclohexyl, adamantyl, or 3chlorophenyl. The secondary pharmacophore consistents of a polar group (ester, ketone, alcohol, or ether) located five/six atoms away from the carbonyl group of the primary pharmacophore. 


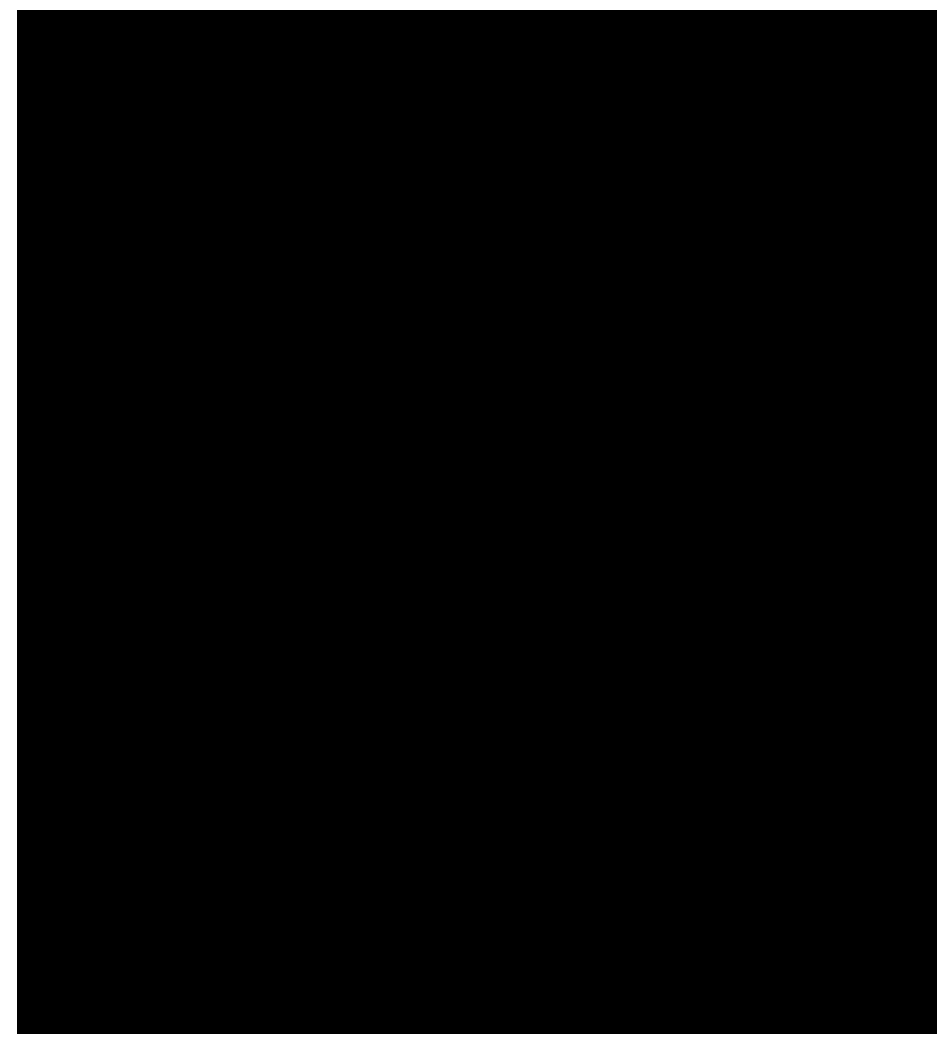

Scheme 1.

Syntheses of 3-Chlorophenyl or Adamantan-1-ylcarbamoylpentanoic Acid Pentyl Ester (7 and 13) and 3-Chlorophenyl- or Adamantan-1-ylacetylaminobutyric Acid Pentyl Ester (8 and 14) ${ }^{a}$

${ }^{a}$ Reagents: (a) 3-chloroaniline (for compound 7) or 1-adamantaneamine (for compound 13), EDCI, DMAP, dichloromethane, rt; (b) 1-bromopentane, potassium carbonate, DMF, rt; (c) (1) 3-chlorophenylacetic Acid (for compound 8), 1-adamantaneacetic acid (for compound 14), or 1-adamantanecarboxylic acid (for compound 15), EDCI, DMAP, dichloromethane, rt, (2) $1 \mathrm{~N}$ aq $\mathrm{NaOH}$, ethanol, rt. 


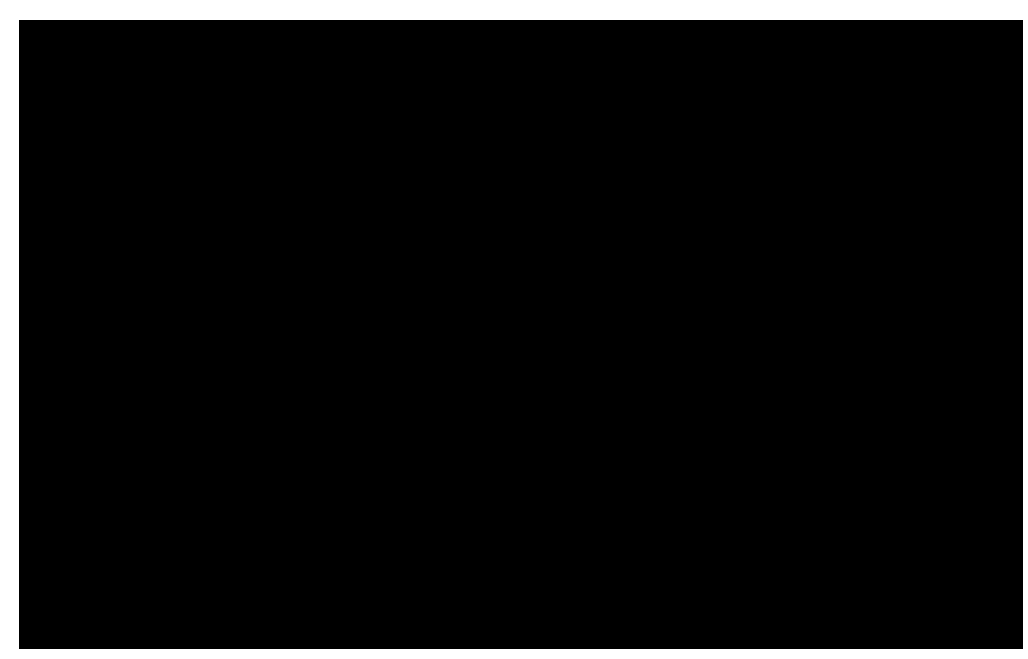

Scheme 2.

Syntheses of 4-Substituted Butyric Acid Pentyl Esters $\left(\mathbf{9}, \mathbf{1 1}\right.$, and 12) ${ }^{a}$

${ }^{a}$ Reagents: (a) pentanol, DMAP, DMF, rt; (b) $\mathrm{BH}_{3}-\mathrm{THF}$ complex, THF, $-10{ }^{\circ} \mathrm{C}_{2} \mathrm{~N}_{2}$; (c) 3chlorophenyl isocyanate, triethylamine, DMF; (d) 3-chlorophenylacetic acid, isobutyl chloroformate, triethylamine, DMF, rt; (e) 4-nitrophenyl chloroformate, triethylamine, DMF, rt; (f) 3-chlorophenol, potassium carbonate, acetonitrile, rt. 


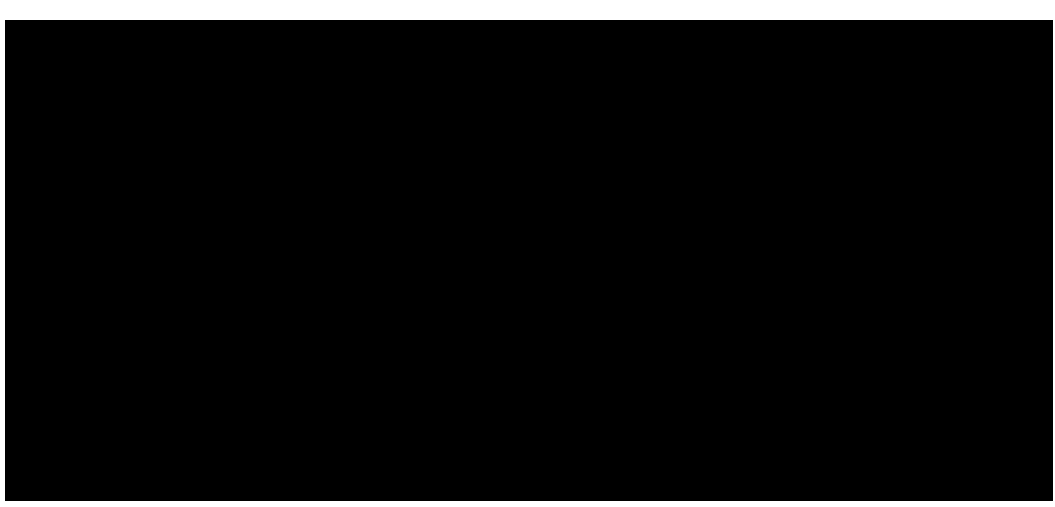

Scheme 3.

Synthesis of 4-(3-Chlorophenoxycarbonylamino)butyric Acid Ethyl Ester (10) ${ }^{a}$ $a$ Reagents: (a) triphosgene, aq $\mathrm{NaHCO}_{3}$ /dichloromethane, rt; (b) 3-chlorophenol, triethylamine, DMF, rt. 


\begin{tabular}{|c|c|c|c|}
\hline \multirow{2}{*}{ No. } & \multirow{2}{*}{ Structure } & Mouse SEH & Hunan sEH' \\
\hline & & \multicolumn{2}{|c|}{$\mathrm{IC}_{50}(\mu \mathrm{M})$} \\
\hline 1 & & $0.05 \pm 0.01$ & $0.17 \pm 0.01$ \\
\hline 2 & & $0.05 \pm 0.01$ & $0.13 \pm 0.01$ \\
\hline 3 & & $0.05 \pm 0.01$ & $0.17 \pm 0.01$ \\
\hline 4 & & $0.05 \pm 0.01$ & $0.11 \pm 0.01$ \\
\hline
\end{tabular}

${ }^{a}$ Enzymes $(0.12 \mu \mathrm{M}$ mouse $8 \mathrm{EH}$ or $0.24 \mu \mathrm{M}$ human $\mathrm{sEH}$ ) were incubated with inhibitors for $5 \mathrm{~min}$ in sodium phosphate buffer (200 $\mu \mathrm{L}$; $\mathrm{pH} 7.4)$ at $30^{\circ} \mathrm{C}$ before substrate introduction $([\mathrm{S}]=40 \mu \mathrm{M})$. Results are means $\pm \mathrm{SD}$ of three separate experiments.

Table 1.

Inhibition of Mouse and Human sEH by 1-Adamantyl-3-alkylureas 


\begin{tabular}{|c|c|c|c|c|c|c|}
\hline \multirow{2}{*}{ No. } & \multirow{2}{*}{$\mathrm{R}$} & \multirow{2}{*}{$\mathrm{x}$} & \multirow{2}{*}{$\mathrm{Y}$} & Mouse sEH ${ }^{2}$ & Human sEH' & \multirow{2}{*}{$\begin{array}{l}m p^{b} \\
\text { (C) }\end{array}$} \\
\hline & & & & \multicolumn{2}{|c|}{$\mathrm{IC}_{50}(\mu \mathrm{M})$} & \\
\hline$(\mathrm{a}-1)$ & & $\mathrm{NH}$ & $\mathrm{NH}$ & $0.06 \pm 0.01$ & $0.16 \pm 0.02$ & 122 \\
\hline (a-2) & & $\mathrm{CH}_{2}$ & NH & $2.1 \pm 0.3$ & $4.0 \pm 0.2$ & 76 \\
\hline (a-3) & & $\mathrm{NH}$ & $\mathrm{CH}_{2}$ & $0.11 \pm 0.01$ & $1.4 \pm 0.2$ & 93 \\
\hline (b-1) & & $\mathrm{NH}$ & NH & $0.07 \pm 0.01$ & $0.19 \pm 0.01$ & 223 \\
\hline (b-2) & & $\mathrm{CH}_{2}$ & NH & $0.58 \pm 0.09$ & $2.1 \pm 0.1$ & 125 \\
\hline (b-3) & & $\mathrm{NH}$ & $\mathrm{CH}_{2}$ & $0.56 \pm 0.06$ & $38 \pm 2$ & 113 \\
\hline$(\mathrm{c}-1)$ & & $\mathrm{NH}$ & NH & $0.71 \pm 0.04$ & $0.23 \pm 0.01$ & 183 \\
\hline (e-2) & & $\mathrm{CH}_{2}$ & $\mathrm{NH}$ & $0.15 \pm 0.01$ & $6.2 \pm 0.2$ & 133 \\
\hline (e-3) & & $\mathrm{NH}$ & $\mathrm{CH}_{2}$ & $1.4 \pm 0.1$ & $4.8 \pm 0.6$ & 121 \\
\hline (d-1) & & $\mathrm{NH}$ & NH & $0.76 \pm 0.02$ & $1.39 \pm 0.02$ & 184 \\
\hline (d-2) & & $\mathrm{CH}_{2}$ & $\mathrm{NH}$ & $3.7 \pm 0.1$ & $16 \pm 2$ & 126 \\
\hline (d-3) & & $\mathrm{NH}$ & $\mathrm{CH}_{2}$ & $2.4 \pm 0.2$ & $14 \pm 2$ & 135 \\
\hline (e-1) & & $\mathrm{NH}$ & NH & $>100$ & $>100$ & - \\
\hline$(e-2)$ & & $\mathrm{CH}_{2}$ & $\mathrm{NH}$ & $>100$ & $>100$ & - \\
\hline (e-3) & & $\mathrm{NH}$ & $\mathrm{CH}_{2}$ & $>100$ & $>100$ & . \\
\hline
\end{tabular}

${ }^{a}$ Enzymes $(0.12 \mu \mathrm{M}$ mouse sEH or $0.24 \mu \mathrm{M}$ human $\mathrm{sEH}$ ) were incubated with inhibitors for 5 min in sodium phosphate buffer (200 $\mu \mathrm{L}$; $\mathrm{pH} 7.4)$ at $30^{\circ} \mathrm{C}$ before substrate introduction $\left([\mathrm{S}]=40 \mu \mathrm{M}\right.$. Results are means $\pm \mathrm{SD}$ of three separate experiments, ${ }^{b}$ mp: melting point.

Table 2.

Inhibition of Mouse and Human sEH by Ureas and the Corresponding Amides Substituted with Liphophilic Groups 


\begin{tabular}{|c|c|c|c|}
\hline \multirow{2}{*}{ No. } & \multirow{2}{*}{ Structure } & Mouse sEH" & Human sEH \\
\hline & & \multicolumn{2}{|c|}{$\mathrm{IC}_{50}(\mu \mathrm{M})$} \\
\hline 5 & & $0.37 \pm 0.04$ & $2.06 \pm 0.07$ \\
\hline 6 & & $0.14 \pm 0.01$ & $3.1 \pm 0.3$ \\
\hline 7 & & $1.7 \pm 0.5$ & $5.9 \pm 0.2$ \\
\hline 8 & & $2.9 \pm 0.2$ & $5.0 \pm 0.5$ \\
\hline 9 & & $17.4 \pm 0.5$ & $25.2 \pm 0.01$ \\
\hline 10 & & $>100$ & $>100$ \\
\hline 11 & & $>100$ & $>100$ \\
\hline 12 & & $>100$ & $>100$ \\
\hline
\end{tabular}

${ }^{\alpha}$ Enzymes $(0.12 \mu \mathrm{M}$ mouse sEH or $0.24 \mu \mathrm{M}$ human $\mathrm{BEH})$ were incubated with inhibitors for $5 \mathrm{~min}$ in sodium phosphate buffer $(200 \mu \mathrm{L}$; $\mathrm{pH} 7.4)$ at $30^{\circ} \mathrm{C}$ before substrate introduction $\left.(\mathrm{S}]=40 \mu \mathrm{M}\right)$. Results are means $\pm \mathrm{SD}$ of three separate experiments,

Table 3.

Inhibition of Mouse and Human sEH by 1-(3-Chlorophenyl)-3-substituted alkylureas 


\begin{tabular}{|c|c|c|c|c|c|c|c|}
\hline \multirow[t]{2}{*}{ No. } & \multirow[t]{2}{*}{ Structure } & $\begin{array}{c}\text { Mouse } \\
\mathrm{sEH}^{\mathrm{a}}\end{array}$ & $\begin{array}{l}\text { Human } \\
\mathrm{sEH}^{\mathrm{a}}\end{array}$ & \multirow{2}{*}{$\begin{array}{c}\mathrm{S}^{\mathrm{b}} \\
(\mu \mathrm{g} / \mathrm{mL})\end{array}$} & \multirow[t]{2}{*}{$\log P^{c}$} & \multirow[t]{2}{*}{$\begin{array}{l}\mathrm{mp}^{d} \\
\left({ }^{\circ} \mathrm{C}\right)\end{array}$} & \multirow[t]{2}{*}{$\log \mathrm{S}^{\circ}$} \\
\hline & & \multicolumn{2}{|c|}{$\mathrm{IC}_{50}(\mu \mathrm{M})$} & & & & \\
\hline 1 & & & $0.17 \pm 0.01$ & $1.44 \pm 0.4$ & $2.77 \pm 0.47$ & 114 & 2.27 \\
\hline 13 & & & $2.4 \pm 0.2$ & $15.1 \pm 1.8$ & $3.53 \pm 0.47$ & oil & 3.32 \\
\hline 14 & & & $0.43 \pm 0.02$ & $17.4 \pm 2.1$ & $3.66 \pm 0.47$ & oil & 3.17 \\
\hline 15 & & $2.8 \pm 0.3$ & $9.4 \pm 0.5$ & $\mathrm{ND}^{f}$ & $\mathrm{ND}^{f}$ & 55 & $\mathrm{ND}^{f}$ \\
\hline 4 & & & $0.11 \pm 0.01$ & $0.50 \pm 0.1$ & $4.76 \pm 0.47$ & 104 & 0.20 \\
\hline 16 & & & $5.0 \pm 0.3$ & $0.42 \pm 0.1$ & $5.52 \pm 0.47$ & 75 & -0.16 \\
\hline 17 & & & $0.10 \pm 0.01$ & $0.32+0.1$ & $5.64 \pm 0.47$ & oil & 0.94 \\
\hline
\end{tabular}

a Enzymes $(0.12 \mu \mathrm{M}$ mouse $\mathrm{sEH}$ or $0.24 \mu \mathrm{M}$ human $\mathrm{sEH}$ ) were incubated with inhibitors for 5 min in sodium phosphate buffer (200 $\mu \mathrm{L}$; $\mathrm{pH} 7.4)$ at $30^{\circ} \mathrm{C}$ before substrate introduction $([\mathrm{S}]=40 \mu \mathrm{M})$. Results are means $\pm \mathrm{SD}$ of three separate experiments. ${ }^{b}$ Experimentally obtained solubility in sodium phosphate buffer $(0.1 \mathrm{M}, \mathrm{pH} 7.4)$ at $25 \pm 1^{\circ} \mathrm{C}$. Results are means $\pm \mathrm{SD}$ of three separate experiments. $P$ calculated by Crippen's method by using $C S$ Chembraw 6.0 version. mp; melting point. "Solubility in water. It was calculated according to the following equation suggested by Banerjee et al.: $\log P=6.5-0.89(\log S)-0.015 \mathrm{mp}$, where mp is melting point. ${ }^{f}$ ND: not determined.

Table 4.

Inhibition of Mouse and Human sEH by 1-Adamantyl-3-alkylureas 